\title{
Beliefs of Moroccans Facing the COVID-19
}

\author{
A. Chaara ${ }^{1 *}$, F. Laboudi ${ }^{1}$, S. Belbachir ${ }^{1}$, A. Ouanass ${ }^{1}$
}

\author{
${ }^{1}$ Arrazi University Psychiatric Hospital in Salé, Ibn Sina University Hospital in Rabat, Faculty of Medicine and Pharmacy in Rabat \\ Mohamed V University, Rabat, Morocco
}

\begin{tabular}{l|l|}
\hline $\begin{array}{l}\text { DOI: } 10.36347 / \text { sasjm.2021.v07i05.003 } \\
\text { *Corresponding author: Aya Chaara }\end{array}$ & | Received: 23.03.2021 | Accepted: 01.05.2021 | Published: 08.05 .2021 \\
\hline Abstract & Original Research Article \\
\hline
\end{tabular}

Despite all the information available on the severity of the virus, there are still people in denial and finding irrational descriptions to explain the Covid 19 pandemic. Indeed, from the start of first pandemics, men considered that it was inexplicable by medicine and only found its origin in the wrath of God, a belief that is still present today. Over the centuries, the perception of pandemics has gone through several stages. From the twentieth century, the conspiracy theory appears. The era of scientific thought and submission to a purely rational theory still clashes with other theories, even today. Any new epidemic brings its share of false beliefs, misconceptions and conspiracy theories. These push communities into hostile behavior that can put their own lives at risk. As for the coronavirus pandemic, it has sparked several interpretations in different cultures, all coming together in irrationality and without scientific basis. Through this work, we will describe and analyze the beliefs of Moroccans facing this pandemic, according to the most widespread theories trying to explain it, in particular scientific, religious, conspiracy and political theory, in order to find a link between these beliefs and different socio-demographic parameters.

Keywords: Beliefs, Covid 19, Religion, Conspiracy, Science, Politics.

Copyright (C) 2021 The Author(s): This is an open-access article distributed under the terms of the Creative Commons Attribution 4.0 International License (CC BY-NC 4.0) which permits unrestricted use, distribution, and reproduction in any medium for non-commercial use provided the original author and source are credited.

\section{INTRODUCTION}

Beliefs are ideas that are not necessarily demonstrated empirically or rationally and through which individuals construct their relationship with the world around them [1].

When nothing comes to explain the eruption of an inconceivable drama - war, famine, natural or human cataclysm, pandemic - beliefs are an inexhaustible source of interpretations, from which religious, political and opportunistic considerations are not excluded [2].

Beliefs provide answers to the puzzles of existence and offer the beginnings of meaning to those who adhere to them. For some people, reality can only be reasonable and anything that diverges from the rational is only the product of a secret thought, constructed by outside forces [3].

Several beliefs have emerged following the Covid 19 pandemic, including religious beliefs in divine punishment or, in an opposite pole, belief in conspiracy with all its aspects, the ultimate goal of which is to control the world.

As for religion, believing that epidemics and natural disasters are due to the anger of Gods towards men and a vengeance against them is an ancient dogma rooted in the distant human past and anthropologists trace it back to the past era of prescientific thought, that human groups developed before the start of civilization. This thought is still relevant today.

In terms of conspiracy, this theory has fascinated for years. Indeed, the introduction of a virus into the population is accomplished with the aim of seeking to conquer the world. To do what ? Dominate it! So a particular organization or country is introducing a virus intended to "cleanse" the planet and subject the survivors to its total domination. This conspiratorial discourse also leads to the belief in biological warfare between different countries.

Beliefs also play a role in the adoption of health behaviors that people consider to be healthy or harmful. The risks they attribute to disease and how they view their health vary according to the characteristics of individuals and their environment [4]. In the current context of the COVID-19 pandemic, with its share of uncertainty and information overload, the beliefs of individuals may further influence the adoption of recommended actions. 
The interest of this work is to describe the beliefs of Moroccans facing the current pandemic, according to the 4 most widespread theories : Religious, conspiratorial, scientific and political. Then, to analyze and correlate these beliefs according to different sociodemographic parameters in order to find a link that could explain them.

\section{MATERIALS AND METHODS}

It is a descriptive and analytical study, developed from a questionnaire exploring the 4 theories already mentioned. This questionnaire explores the socio-demographic characteristics (age, sex, profession, level of education and socio-economic level), religiosity and the theory(s) that may explain this pandemic according to each individual.

It was posted online to target the general population. Anyone with a disease affecting judgment was excluded. This study was carried out between April and May 2020.

The sample was selected randomly and the univariate descriptive and analytical analyzes were performed using SPSS software.

\section{Descriptive Statistics}

312 responses were collected.

Table-1: The socio-demographic characteristics of the sample and the theory adopted by each individual

\begin{tabular}{|l|l|l|}
\hline $\begin{array}{l}\text { Socio-demographic characteristics and the theory adopted by each } \\
\text { individual. }\end{array}$ & $\begin{array}{l}\text { N } \\
(\%)\end{array}$ \\
\hline \multirow{4}{*}{ Age } & $<18$ years old & $0,1 \%$ \\
\cline { 2 - 3 } & $18-30$ years old & $53 \%$ \\
\cline { 2 - 3 } & $31-50$ years old & $37,3 \%$ \\
\cline { 2 - 3 } & $>50$ years old & $9,2 \%$ \\
\hline \multirow{5}{*}{ Educational level } & Female & $67,3 \%$ \\
\cline { 2 - 3 } & Male & $32,1 \%$ \\
\hline Profession & High & $96,2 \%$ \\
\cline { 2 - 3 } & Secondary & $3,8 \%$ \\
\hline \multirow{5}{*}{ Adopted theory } & Employees or civil servants & $67,5 \%$ \\
\cline { 2 - 3 } & Students & $14,1 \%$ \\
\cline { 2 - 3 } & Private jobs & $8 \%$ \\
\cline { 2 - 3 } & Without a job & $8 \%$ \\
\cline { 2 - 3 } & Day laborer & $5,1 \%$ \\
\cline { 2 - 3 } & Retired & $2,9 \%$ \\
\hline & Scientific theory & $24,4 \%$ \\
\cline { 2 - 3 } & Political theory & $42,9 \%$ \\
\cline { 2 - 3 } & Conspiracy theory & $25 \%$ \\
\cline { 2 - 3 } & Religious theory & \\
\hline
\end{tabular}

To explore each theory, we have proposed several hypotheses based on the beliefs prevalent at the time of the pandemic. Indeed, the exploration of scientific theory goes in favor that it is a proven virus $(90.1 \%)$, resembling to other existing pandemics $(62.5 \%)$ and that the measures taken by the government are effective and judicious in more than $88 \%$ of cases. Nevertheless, we see that traditional medicine still has a place in the beliefs of Moroccans in 26\% who encourage this practice in order to protect themselves against the disease.

From a religious point of view, several propositions have been put forward to explain this wrath of God. The most evoked is an affliction in $87.7 \%$ of the responses, regardless of age, profession or level of education, followed by withdrawal from religious practice in $81.6 \%$ of cases, all theories combined. $65.8 \%$ of the participants believe that it is a divine punishment, a sign of divine discontent linked to the legalization of alcohol in holy places and of homosexuality in several countries. Removal or distraction from religious practice is also mentioned in $55.2 \%$ of those believing in a biological warfare and in $57.5 \%$ of those believing in a conspiracy theory.

Still in the religious context, $51.9 \%$ of the population are for the funeral enema even if it is prohibited by law in the current pandemic, $31.7 \%$ are also for funerals and $8 \%$ are for the transgression of The confinement's laws.

As for political theory, $42 \%$ of cases believe it to be biological warfare led by either the United States or China, evenly distributed.

Regarding the conspiratorial nature of this pandemic, $25.6 \%$ believe in it. The response validated by $63.8 \%$ of participants is the possibility that the virus was manipulated into this more virulent strain before being spread in population. $26 \%$ of the sample think that this pandemic is created to acquire the $5 \mathrm{G}$ market, $28.2 \%$ think that it is a mean to control demographic expansion and $27.6 \%$ believe that it is a method that the 
WHO created for purely commercial purposes. Even for those who voted for the other theories, it is observed that $55.6 \%$ of them believe that the virus has been manipulated.

To sum up these beliefs, $90 \%$ of the population assume that science and religion complement each other. For $30 \%$ of the population, there is no connection between science and politics or between politics and religion. While for about $40.4 \%$ of the population, politics and religion complement each other.

\section{Univariate Analytical Statistics}

\section{Religiosity}

Our sample consists of $96.8 \%$ believers and $3.2 \%$ unbelievers. As for the Muslim practice, $58.6 \%$ say that they practice religion assiduously, $36.9 \%$ from time to time, while $4.5 \%$ are not practicing.

To assess this religious practice, the question was asked about the different pillars of Islam, in order to determine the degree of attendance of each.

The results show that $93.9 \%$ fast diligently, while prayer and almsgiving are practiced in $66.3 \%$ and $64.4 \%$ respectively.

Table-2: Correlation between the degree of religious practice and that of attendance in each pillar of religion

\begin{tabular}{|c|c|c|c|c|}
\hline \multirow[t]{2}{*}{$\begin{array}{l}\text { Correlation between religious practice and } \\
\text { the attendance in each pillar of religion. }\end{array}$} & & Assiduously & $\begin{array}{l}\text { From time to } \\
\text { time }\end{array}$ & No \\
\hline & \multicolumn{4}{|l|}{ PRAYER } \\
\hline \multirow{11}{*}{ RELIGIOUS PRACTICE } & Assiduously & 170 & 11 & 0 \\
\hline & From time to time & 36 & 66 & 12 \\
\hline & No & 1 & 1 & 12 \\
\hline & \multicolumn{4}{|l|}{ RAMADAN } \\
\hline & Assiduously & 180 & 0 & 0 \\
\hline & From time to time & 110 & 5 & 0 \\
\hline & No & 3 & 2 & 9 \\
\hline & \multicolumn{4}{|l|}{ ALMS } \\
\hline & Assiduously & 135 & 30 & 10 \\
\hline & From time to time & 63 & 35 & 16 \\
\hline & No & 3 & 3 & 8 \\
\hline
\end{tabular}

\section{Theory adopted by our sample According to age}

The age group most represented in our sample is $18-30$ years (53\% of the total sample). This category essentially believes in the scientific reality of the current pandemic but also in the possibility that it is a biological war with a percentage of $45.5 \%$.

The same is observed for the 31-50 age group, which puts scientific theory first in $81.9 \%$ of respondents, followed by the possibility of a biological warfare in $45.5 \%$.

The people questioned who are over 50 tend mainly to scientific theory; by stating that it is indeed a confirmed viral attack in $82.1 \%$. Biological warfare is also suspected in $28.6 \%$, followed by religious theory which states that Covid is a divine revenge, and finally $17.9 \%$ believe it to be a conspiracy.

Thus, we notice that the more we advance in age, the more scientific theory takes precedence over other theories. However, age is not significantly related to any specific theory.

\section{According to sex}

It can be seen that the female sex is the most represented in all the theories presented. However, there is no significant difference between the two sexes regarding the theory adopted.

\section{According to the profession}

Public and liberal offices lean towards scientific theory followed by political theory, stating that the pandemic is biological warfare. The same goes for people with another job, such as a day laborer for example, with a percentage of $56.25 \%$ for the theory of war.

Divine revenge and conspiracy theory share the same percentages among retirees and those without office and come last after biological warfare theory and the scientific theory that stays ahead.

As a result, occupation does not significantly influence the belief of our sample.

\section{According to the level of education}

Regarding the level of education, whether secondary or higher, the theory most represented in the two groups is the scientific one.

In contrast, divine vengeance is more common among people with secondary education than those with higher education, with percentages of $40 \%$ and $24 \%$ respectively. We find the same thing for the conspiracy theory, which is present in $60 \%$ of the population with a 
secondary level of education, unlike $25 \%$ in those with a higher level of education.
The difference is not significant in the theory of war. So, the lower the level of education, the more one believes in conspiracy and divine vengeance.

Table-3: Correlation between socio-demographic parameters and the different theories adopted

\begin{tabular}{|c|c|c|c|c|c|c|c|c|c|}
\hline \multicolumn{2}{|c|}{$\begin{array}{l}\text { Correlation between } \\
\text { socio-demographic } \\
\text { parameters and the } \\
\text { different theories } \\
\text { adopted. }\end{array}$} & \multicolumn{2}{|c|}{ Scientific theory } & \multicolumn{2}{|c|}{ Religious theory } & \multicolumn{2}{|c|}{ Political theory } & \multicolumn{2}{|c|}{$\begin{array}{l}\text { Conspiracy } \\
\text { theory }\end{array}$} \\
\hline \multirow[t]{4}{*}{ Age } & $<18$ yo & $1(50 \%)$ & \multirow[t]{4}{*}{$\mathrm{p}=\mathbf{0 , 7}$} & $0(50 \%)$ & \multirow[t]{4}{*}{$p=0,465$} & $0(50 \%)$ & \multirow[t]{4}{*}{$\mathrm{p}=\mathbf{0 , 3 1 2}$} & $0(50 \%)$ & \multirow[t]{4}{*}{$p=0,641$} \\
\hline & 18-30 yo & $\begin{array}{l}127 \\
(77 \%)\end{array}$ & & $\begin{array}{l}36 \\
(21,9 \%)\end{array}$ & & $\begin{array}{l}75 \\
(45,5 \%)\end{array}$ & & $\begin{array}{l}46 \\
(27,9 \%)\end{array}$ & \\
\hline & 31-50 yo & $\begin{array}{l}95 \\
(81,9 \%)\end{array}$ & & $\begin{array}{l}34 \\
(29,3 \%)\end{array}$ & & $51(44 \%)$ & & $\begin{array}{l}29 \\
(25 \%)\end{array}$ & \\
\hline & $>50$ yo & $\begin{array}{l}23 \\
(82,1 \%)\end{array}$ & & $\begin{array}{l}6 \\
(21,4 \%)\end{array}$ & & $\begin{array}{l}8 \\
(28,6 \%)\end{array}$ & & $\begin{array}{l}5 \\
(17,9 \%)\end{array}$ & \\
\hline \multirow[t]{2}{*}{ Sexe } & Female & $\begin{array}{l}167 \\
(79,5 \%)\end{array}$ & \multirow[t]{2}{*}{$p=0,91$} & $\begin{array}{l}57 \\
(27,1 \%) \\
\end{array}$ & \multirow[t]{2}{*}{$p=0,119$} & $\begin{array}{l}96 \\
(45,7 \%)\end{array}$ & \multirow[t]{2}{*}{$\mathrm{p}=0,2$} & $\begin{array}{l}55 \\
(26,2 \%) \\
\end{array}$ & \multirow[t]{2}{*}{$p=0,823$} \\
\hline & Male & $79(79 \%)$ & & $19(19 \%)$ & & $38(38 \%)$ & & $\begin{array}{l}25 \\
(25 \%)\end{array}$ & \\
\hline \multirow[t]{6}{*}{ Profession } & Other & $\begin{array}{l}13 \\
(81,25 \%)\end{array}$ & \multirow[t]{6}{*}{$p=0,193$} & $\begin{array}{l}5 \\
(31,25 \%) \\
\end{array}$ & \multirow[t]{6}{*}{$p=0,636$} & $\begin{array}{l}9 \\
(56,25 \%)\end{array}$ & \multirow[t]{6}{*}{$p=5,46$} & $4(25 \%)$ & \multirow[t]{6}{*}{$p=0,249$} \\
\hline & Student & $\begin{array}{l}29 \\
(65,9 \%)\end{array}$ & & $\begin{array}{l}7 \\
(15,9 \%)\end{array}$ & & $\begin{array}{l}16 \\
(36,4 \%)\end{array}$ & & $\begin{array}{l}8 \\
(18,2 \%)\end{array}$ & \\
\hline & Private & $19(76 \%)$ & & $7(28 \%)$ & & $8(32 \%)$ & & $3(12 \%)$ & \\
\hline & Retired & $\begin{array}{l}4 \\
(66,7 \%)\end{array}$ & & $\begin{array}{l}1 \\
(16,7 \%)\end{array}$ & & $\begin{array}{l}2 \\
(33,3 \%) \\
\end{array}$ & & $\begin{array}{l}1 \\
(16,7 \%)\end{array}$ & \\
\hline & $\begin{array}{l}\text { Employee } \\
/ \quad \text { Civil } \\
\text { servant } \\
\end{array}$ & $\begin{array}{l}175 \\
(82,9 \%)\end{array}$ & & $\begin{array}{l}55 \\
(26,1 \%)\end{array}$ & & $\begin{array}{l}96 \\
(45,5 \%)\end{array}$ & & $\begin{array}{l}63 \\
(30 \%)\end{array}$ & \\
\hline & Without & $6(75 \%)$ & & $\begin{array}{l}1 \\
(12,5 \%)\end{array}$ & & $\begin{array}{l}3 \\
(37,5 \%)\end{array}$ & & $\begin{array}{l}1 \\
(12,5 \%)\end{array}$ & \\
\hline \multirow[t]{2}{*}{$\begin{array}{l}\text { Educa- } \\
\text { tion }\end{array}$} & Secondary & $8(80 \%)$ & \multirow[t]{2}{*}{$p=0,959$} & $4(40 \%)$ & \multirow[t]{2}{*}{$p=0,247$} & $4(40 \%)$ & \multirow[t]{2}{*}{$\mathrm{p}=\mathbf{0 , 8 3 4}$} & $\begin{array}{l}6 \\
(60 \%) \\
\end{array}$ & \multirow[t]{2}{*}{$\mathrm{p}=\mathbf{0 , 0 1 2}$} \\
\hline & High & $\begin{array}{l}238 \\
(79,3 \%)\end{array}$ & & $72(24 \%)$ & & $\begin{array}{l}130 \\
(43,3 \%)\end{array}$ & & $\begin{array}{l}74 \\
(25 \%) \\
\end{array}$ & \\
\hline
\end{tabular}

\section{Funeral Rites}

In the same sense, and knowing that the mortuary rituals are well codified in the Muslim religion, the various participants were asked to answer if they would respect the measures imposed by the state or not, and we correlated their answers with age and level of education.

\section{According to age}

Regardless of age, $31.7 \%$ of participants are in favor of performing funerals even when reunions are prohibited by law. Thus, age significantly influences this belief $(\mathrm{p}=0.002)$.
As for the mortuary enema, opinions are divided between its authorization and its prohibition, with a slight predominance for its authorization in people over 50 years old and people aged between 18 and 30 years $(\mathrm{p}<10-3)$.

\section{According to the level of education}

The level of study does not significantly influence the convictions of our sample, since between $52.3 \%$ and $60 \%$ of cases, regardless of the level of education, are still for the mortuary enema despite its ban $(p=0.863)$, and between $31.9 \%$ and $40 \%$ of cases are for the performance of funerals $(\mathrm{p}=0.835)$. 
Table-4: Correlation between funeral rites with age and level of education

\begin{tabular}{|l|l|l|l|l|l|}
\hline \multicolumn{2}{|c}{} & Funeral & \multicolumn{2}{l|}{ Mortuary enema } \\
\cline { 3 - 6 } Age & No & Yes & No & Yes \\
& <18 years old & 1 & 0 & 1 & 0 \\
& $>$ 50 years old & $19(73,1 \%)$ & $7(26,9 \%)$ & $12(46,2 \%)$ & $\mathbf{1 4}(\mathbf{5 3 , 8 \%})$ \\
& $\mathbf{1 8 - 3 0}$ years old & $114(68,3 \%)$ & $53(31,7 \%)$ & $69(41,3 \%)$ & $\mathbf{9 8}(\mathbf{5 8 , 7 \%})$ \\
& $\mathbf{3 1 - 5 0}$ years old & $77(66,8 \%)$ & $39(33,2 \%)$ & $\mathbf{6 4}(\mathbf{5 5 , 2 \%})$ & $52(44,8 \%)$ \\
\hline Educational & Secondary & $6(60 \%)$ & $\mathbf{4 ( 4 0 \% )}$ & $4(40 \%)$ & $\mathbf{6 ( 6 0 \% )}$ \\
level & High & $203(68,1 \%)$ & $\mathbf{9 5}(\mathbf{3 1 , 9 \% )}$ & $142(47,6 \%)$ & $\mathbf{1 5 6}(\mathbf{5 2 , 3 \%})$ \\
\hline
\end{tabular}

\section{DISCUSSION}

The immense crisis caused by months of the coronavirus epidemic gives rise every day, from one end of the world to the other, to multiple attempts of interpretations.

\section{Religious Theory}

The misfortunes of the times, epidemics, famines or military defeats are always part of the great divine plan for humanity.

There is no study or survey done in this direction, to assess the prevalence of this theory in other populations. Nevertheless, for the current pandemic, the religious have interpreted it. The rabbi Meir Mazuz claimed the coronavirus was a divine punishment caused by the Gay Pride parade. Daesh Islamists also interpret the coronavirus as a punishment from God against infidels. The conservative pastor Rick Wiles, meanwhile, asserted that the spread of coronavirus in synagogues was "a punishment from God for those who oppose Jesus."

Politicians also had their say. The Zimbabwean Minister of Defense Mrs Oppah Muchinguri, during a rally on March 14, 2020 in Chinhoyi, described the coronavirus pandemic as a "divine punishment" inflicted on the United States and the European Union, because they applied sanctions to his country because of its repression against the opposition: "The coronavirus is the work of God who punishes the countries which have imposed sanctions on us [...] They must feel the effects of the coronavirus to understand our pain" [6].

For Ralph Drollinger, a US religious minister who heads a Bible study group around the US president, the crisis is "an act of divine judgment". The Covid-19 would express "the wrath of God" not on America, but against Americans, some of whom have practiced the cult of "environmentalism" and expressed their penchant for "lesbianism and homosexuality". This claim ties in with a belief so prevalent in our sample that divine retribution is a response to the permissibility of homosexuality in the world.

In China, even President Xi Jinping, during his meeting with the General Director of the World Health Organization (WHO) at the end of January 2020, when the coronavirus contamination was on the rise, the
Chinese president said: "The epidemic is a demon and we cannot keep it hidden".

In Algeria, The Imam Chems Eddine Aldjazairi said on Facebook to be "afraid that God has sent us this virus so that we can come back to him and when he sees that we have closed the mosques, he will send us another virus even more virulent".

In Morocco, "the epidemics are soldiers of God (...) angry for God and take revenge for him (...) God uses them to discipline men so that they turn to their creator", declared the group "Justice and Charity".

In our study, the responses are similar between the different propositions, with a response of $42.6 \%$ for estrangement from religious practice and over $81 \%$ for affliction.

Religious authorities, for the most part, support measures to combat the spread of the coronavirus. However, In some countries, clerics have shouted "apostasy" and warned against the wrath of God after the closure of places of worship, as it is the case of the Salafist preacher Abu Naim, who accused the authorities by "apostasy" for having decided to close places of worship. He was arrested for "terrorism".

In contradiction to the strict rules of containment, religion has also been implicated in the spread of the virus [7]. Indeed, in Israel, for weeks, ultra-Orthodox neighborhoods disdained state restrictions. In Jerusalem, $74 \%$ of those who tested positive come from the ultra-Orthodox neighborhoods of the city [8]. In South Korea, where the epidemic spread in early February, many of those infected belonged to a marginal Christian group, the Shincheonji Church of Jesus. In Iran, in Qom, believers have been seen massing in Shiite shrines. In St. Petersburg, hundreds of believers kissed icons at an exhibition of the relics of St. John the Baptist from Jerusalem. In Brazil, President Jair Bolsonaro has declared evangelical churches as an essential sector and therefore not subject to a temporal closure [9]. The Greek Orthodox Church rejected the idea that the fellowship of the faithful could promote the transmission of the virus [10].

Funeral rites such as mortuary washing and large-scale religious ceremonies are momentarily 
impossible and force religious leaders to find new ways to celebrate death religiously. In our sample, $51.9 \%$ of the population are for the mortuary enema even if it is prohibited by law in the current pandemic, $31.7 \%$ are also for the funeral and $8 \%$ are for the transgression of containment laws.

Regarding religiosity, we have not found an article defining it since each culture determines it individually. We therefore compared the degree of practice of each individual with the image he gives himself on the definition of religiosity. Thus, we can derive a definition of the concept of religiosity from our sample. In fact, to be diligent, practicing Ramadan comes first, then comes prayer and finally alms. We also notice that, even when calling themselves a nonpractitioner, a sample patient still gives alms first, Ramadan second, and prayer last.

Thus, the image of good Muslim practice is defined, according to our sample, first by fasting, followed by alms and then by prayer.

\section{Ecosystem and COVID}

Religious are not the only ones to express this idea of divine punishment. We also talk about the revenge of nature. The latter would seek to punish the human species for its multiple predations, whether it is the disappearance of animals, the destruction of forests or the diversion of large rivers [11]. Humanity is then seen as "a huge coronavirus for the planet, since it blocks all of its airways".

Inger Andersen, director of the United Nations Environment Program (UNEP), gave an interview to the British daily The Guardian "Mankind has put too much pressure on ecosystems, and we are now paying the consequences", declared she.

In our sample, several people added this theory in the section intended for "Other possible theories":

- "It is a viral mutation, following the climatic changes that the planet is undergoing because of Man".

- $\quad$ Maybe God programmed this pandemic in order to preserve the environment".

- $\quad$ "Nature defends itself against its worst kind".

- $\quad$ "The coronavirus is due to anger of nature".

- "What we are experiencing is nothing other than the purification of the earth".

\section{Conspiracy and political theories}

The conspiratorial explanations are very diverse, and can relate either to "event conspiracy" (for example: the Covid19 was created by the pharmaceutical industry or by a laboratory, in order to be able to sell vaccines) or to "mega-conspiracy" : in this case, the invention of Covid19 would only be one of the many manifestations of a much larger conspiracy woven by a powerful group seeking to dominate the world (the Illuminati, the Chinese, etc.) [5].

More than a quarter (26\%) of French people believe that the new coronavirus was manufactured in the laboratory, including $17 \%$ "intentionally", and the latter figure jumped to $40 \%$ among supporters of the National Rally, according to a study by the Institute for Opinion and Marketing Studies in France and Abroad, published on March 28, on a sample of 1,008 people representative of the French population, aged 18 and over, from March 24th to 26th.

The coronavirus "appeared naturally" for $57 \%$ of French people, but $17 \%$ believe that it was developed "intentionally" in a laboratory "and $9 \%$ that it was made" accidentally "in the laboratory, according to the study carried out for the Jean-Jaurès foundation and the Observatory of conspiracy Conspiracy Watch [12].

The Institute for Opinion and Marketing Studies in France and Abroad conducted the study after the publication of a similar survey by the Pew Research Center conducted in the United States from March 10th to 16th. According to the study cited, $29 \%$ of Americans believe that the coronavirus was made in a laboratory (23\% "intentionally" and 6\% "accidentally"), compared to $43 \%$ who think it appeared naturally. Some $25 \%$ do not comment. The study also confirms previous surveys which showed that "the youngest generations and the most disadvantaged social categories remain the most susceptible to conspiracy". Thus, $27 \%$ of those under 35 think that the virus was developed "intentionally" in a laboratory against only $6 \%$ of those over 65 years old. The poor categories believe that the virus was made "intentionally" in the laboratory in $22 \%$, while the better-off categories are only $4 \%$.

Workers $(28 \%)$ and employees $(24 \%)$ are more sensitive to this conspiracy thesis than the selfemployed (13\%) and managers (12\%). Unemployed respondents are also more likely (28\%) than those questioned exercising a professional activity (20\%) to believe that this virus was manufactured in the laboratory.

According to a Canadian study, During the month of June, more than a third (35\%) of respondents felt that the government was withholding important information about the pandemic from them and $12 \%$ knew nothing about it. One in four respondents (23\%) believed the virus was created in the laboratory, and a similar proportion did not know. Fewer believed there was a link between $5 \mathrm{G}$ telecommunications towers and the virus $(6 \%)$. However, $15 \%$ admitted not knowing it.

There are few differences according to the sex of the respondents. Those between the ages of 18 and 59 are more likely to agree with these conspiracy 
theories. Those whose household income has declined significantly since the pandemic, who are unemployed or off work due to the pandemic, and those who are more materially disadvantaged seemed to adhere more to these beliefs. Among healthcare workers, 28\% believed the virus was developed in the lab and $13 \%$ believed there was a link between the virus and $5 \mathrm{G}$ telecommunications towers. Finally, respondents with a high school education or less believed more that the government was hiding information from them (40\%) and that the virus was a laboratory creation (30\%) [13].

Another poll was carried out on the Moroccan electronic newspaper "Hespress", which recruited 59,792 people, showing that $27.27 \%$ believe in the conspiracy thesis, and $21.56 \%$ in divine vengeance.

In the same context, videos accusing the Rothschilds of profiting from the epidemic circulated during the pandemic; others still claiming that the virus does not exist but is intended for "a universal vaccination campaign with microchip". Conspiracy theories have been swarming for weeks around the pandemic caused by Covid-19 [14].

A sociological study, published in the British journal Royal Society Open Science, explored the content of these theories and the consequences for their followers. The results show that the issue of vaccination is at the heart of these misconceptions. "We found a clear link between believing in conspiracy theories and reluctance towards a future vaccine," said one of the authors of this study, Sander van der Linden, a researcher in social psychology at the University of Cambridge, England.

This study is based on opinion polls carried out in the United Kingdom (two successive waves of around 1,000 participants), the United States, Ireland, Mexico and Spain (700 participants each time). Based on the responses, the researchers estimate that up to a third of the population in some countries is likely to believe in false information and conspiracy theories about Covid-19, which have the effect of increasing distrust of Covid-19 vaccination.

The false theory that participants adhere to the most is that the coronavirus was deliberately manufactured in a laboratory in the Chinese city of Wuhan. Some $37 \%$ of Spanish participants and $33 \%$ of Mexican participants consider this theory "reliable", the same for $22 \%$ and $23 \%$ of respondents in the United Kingdom and the United States. And the false claim saying that the Covid-19 pandemic "is part of a plan to impose global vaccination" is deemed reliable by $22 \%$ of Mexican participants, $18 \%$ of Irish, Spanish and American participants, and $13 \%$ of participants British.

Among the theories of conspiratorial discourse, the emergence of the new coronavirus which would have been created by China, the United States, the pharmaceutical industries or even France, to name just a few examples among those disseminated at the start of the health crisis.

A conspiracy theory has circulated a lot on the web in recent weeks. According to a New York Times study, this is even the second most widely reported "fake news" on social media, after one claiming that Bill Gates is the main organizer of the pandemic. The theory suggests a link between $5 \mathrm{G}$ and Coronavirus: the new technology would facilitate and accelerate the spread of Covid-19 by broadcasting it via the radio waves used to transport information.

As far as our sample is concerned, the Moroccans no less conspiratorial than the French, Americans or Canadians. Indeed, $25.6 \%$ believe in the conspiracy theory. Responses were split between several submissions, with a strong belief that the virus would be manipulated in laboratories before being spread to the population. Even for those who voted for the other theories, it is observed that a total of 128 out of 230 people $(55.6 \%)$ believe that the virus has been manipulated.

\section{CONCLUSION}

In the midst of the Covid19 pandemic, many find refuge in baseless interpretations, just like what has happened with other pandemics.

The Moroccan sample is no exception when it comes to interpretations of this pandemic. However, the urgency is to empower communities of human beings to protect themselves from the virus, whether the subject is conservative, religious or conspiratorial.

Rites have been abandoned, desecration committed, measures deemed contrary to dogmas have been taken, traditions have been flouted, conspiratorial accusations used, ecological theories invented. Reproaches will be made to the spiritual authorities who have accepted the precautionary instructions of the States. The main thing is to believe in a scientific basis for this health crisis because many people are likely to believe in all the possible interpretations and would, perhaps, be influenced in the future, to warn against any vaccination.

\section{BIBLIOGRAPHY}

1. 1 Matot JP. Croire, sans doute, exister, peut-être..., Cahiers de psychologie clinique, 2005/2 ( $\left.\mathrm{n}^{\circ} 25\right)$, p. 111-131. DOI: $10.3917 / \mathrm{cpc} .025 .0111$

2. Cristian J. Les croyances religieuses au défi du Covid-19, publié le 17/04/2020.

3. Zajenkowski M, Jonason PK, Leniarska M, Kozakiewicz Z. Who complies with the restrictions to reduce the spread of COVID-19?: Personality and perceptions of the COVID-19 situation. 
Personality and Individual Differences. 2020 Nov 1;166:110199.

4. Godin G, Kok G. The theory of planned behavior: a review of its applications to health-related behaviors. American journal of health promotion. 1996 Nov;11(2):87-98.

5. Van Bavel JJ, Baicker K, Boggio PS, Capraro V, Cichocka A, Cikara M, Crockett MJ, Crum AJ, Douglas KM, Druckman JN, Drury J. Using social and behavioural science to support COVID-19 pandemic response. Nature human behaviour. 2020 May;4(5):460-71.

6. https://www.francetvinfo.fr/monde/afrique/politiqu e-africaine/au-zimbabwe-le-coronavirus-est-vucomme-une-punition-de-dieu-contre-lesoccidentaux_3869655.html. France Info, publié le $16 / 03 / 2020$

7. https://www.franceculture.fr/religion-etspiritualite/confinement-comment-les-cultessorganisent?utm_medium=Social\&utm_source=Fa cebook\#Echobox $=1587286242$. France Culture, publié le 20/04/2020
8. Nir H, Aaron R. About 75 Percent of Jerusalem Coronavirus Cases Are Haredi, publié le 08/04/2020.

9. Impact Du Covid-19 Dans Les Milieux Religieux Et Spirituels, Centre d'information sur les croyances, publié 20/04/2020.

10. Nick K. Greek Orthodox Church Declares Coronavirus Not Transmitted by Communion, publié le 9/03/2020

11. Joël ÉS. Covid-19 et la tentation eschatologique. Le Point.fr, publié le 20/05/2020.

12. Lucie S. Comment le Coronavirus est devenu un terrain fertile pour les théories e complot. Le monde, publié le 28/03/2020.

13. Ève D. COVID-19 - Pandémie, croyances et perceptions, publié le 03/08/2020 à l'Institut national de santé publique de Québec.

14. Lionel M. Complot des laboratoires ou vengeance de la nature : le dualisme résiste au COVID-19, publié le 01/04/2020 à Socialter.

15. Daisuke W, Davey A, Marc T. Bill Gates, at Odds With Trump on Virus, Becomes a Right-Wing Target, publié le 17/04/2020 à New York Times. 